\author{
UNIVERSIDADE DE SÃO PAULO \\ FACULDADE DE FILOSOFIA, LETRAS E CIÊNCIAS HUMANAS \\ DEPARTAMENTO DE LETRAS CLÁSSICAS E VERNÁCULAS \\ Estudos Comparados de Literaturas de Língua Portuguesa
}

\title{
Um estudo da temporalidade nos romances \\ O Amanuense Belmiro e Para Sempre
}

Maristela Reggiani

Trabalho apresentado ao Departamento de Letras

Clássicas e Vernáculas, área de Literatura

Comparada de Países de Língua Portuguesa, da Universidade de São Paulo, com vistas ao título de Mestre, sob a orientação da $\operatorname{Prof}^{\text {a. }} \operatorname{Dr}^{\text {a. }}$ Benilde Justo Caniato.

$1^{0}$ sem./2007 
"Em certo sentido, toda vida, quando narrada, é exemplar; escrevemos para atacar ou para defender um sistema do mundo, para definir um método que nos é próprio. E não é menos verdade que é pela idealização ou pela crítica mordaz a todo custo, pelo detalhe fortemente exagerado ou prudentemente omitido, que se desqualificam quase todos os biógrafos: o homem construído substitui o homem compreendido. Nunca perder de vista o gráfico de uma vida humana, que não se compõe, digam o que disserem, de uma horizontal e de duas perpendiculares, mas de três linhas sinuosas, prolongadas até o infinito, incessantemente reaproximadas e divergindo sem cessar: o que o homem julgou ser, o que ele quis ser, e o que ele foi." (Marguerite Yourcenar. Memórias de Adriano) 


\section{DEDICATÓRIA}

A meus pais, Ernesto Reggiani e Odila Rodeguer Reggiani, que me ensinaram a amar as coisas simples. 
AGRADECIMENTOS ESPECIAIS

À amiga e orientadora Prof ${ }^{\text {a. }}$ Benilde Justo Caniato, pela confiança e dedicação.

Sua serenidade foi imprescindível à execução deste trabalho. 
AGRADECIMENTOS ESPECIAIS

Ao Carlos, que esteve a meu lado no prazer e nas dificuldades deste trabalho.

A você, serei sempre grata pelas pertinentes sugestões e pela cuidadosa revisão. 


\section{AGRADECIMENTOS}

Ao Prof. Dr. Reginaldo Pinto de Carvalho e à Prof ${ }^{\text {a. }}$ Dr $^{\text {a. }}$ Tânia Macedo, pelas sugestões no Exame de Qualificação.

Ao Prof. Dr. Luis Ferraz, da Universidade de Caen, pelo material fornecido e pelas nossas conversas sobre Cyro dos Anjos.

À FAPESP, pela bolsa de estudos.

Ao Jorge, por estar sempre comigo.

Ao Paulo, por compartilhar comigo a paixão pelos livros.

Às amigas Regina, Ruth e Zélia, que, de diferentes formas, participaram deste processo.

À Cina, tão doce, que apareceu em minha vida quando pensamos ser difícil fazer novos amigos.

À tia Tim e ao Michel, por colocarem a minha disposição a vista para o mar.

Finalmente, agradeço ao tio Luis (em memória) e à tia Ivone, mais amiga do que tia, porque, sem seu estímulo, eu não teria trilhado este caminho. A vocês, a quem devo o início de tudo, minha mais profunda gratidão. 


\section{RESUMO}

O objetivo deste trabalho é, à luz da Literatura Comparada, tecer uma rede de vínculos entre os romances O Amanuense Belmiro, de Cyro dos Anjos, e Para Sempre, de Vergílio Ferreira, para cotejá-los, realçando suas semelhanças e dessemelhanças, e, conseqüentemente, compreendê-los melhor.

Para isso, após breves considerações sobre determinados conceitos relativos à composição do romance, como enunciado e enunciação, narrador e narratário, o foco narrativo, o espaço e a personagem, centralizamos a discussão no conceito de tempo distinguindo três noções: tempo físico, tempo interior e tempo lingüístico, com destaque para as duas últimas - e o utilizamos como eixo no estudo das obras, na intenção de verificar como os narradores-personagens vêem seu passado e vivem seu presente.

No que tange ao tempo lingüístico, privilegiamos o estudo do uso dos verbos, dentre outras palavras temporais, a fim de verificarmos os efeitos de sentido nas escolhas dos dois autores; quanto ao tempo interior, que não é marcado pelo relógio, mas pela intensidade com que as personagens vivem diferentes momentos, enfatizamos o estudo da relação das personagens com o passado.

Também, em virtude da clara diferença entre os tipos de romance analisados, destinamos considerável parte do trabalho ao estudo do gênero narrativo.

\section{PALAVRAS-CHAVE}

TEMPO, ESPAÇO, NARRADOR-PERSONAGEM, ROMANCE-DIÁRIO, ROMANCE-INTIMISTA 


\section{RÉSUMÉ}

L'objectif de ce travail est, à la lumière de la Literature Comparée, tisser un réseau de liens entre les romans O Amanuense Belmiro, de Cyro dos Anjos, et Para Sempre, de Vergílio Ferreira, pour les comparer mettre en consequence mieux les comprendre.

Pour cela, aprés de curtes considerations sur des concepts déterminés, relatifs à la compositions du roman tel que, énoncé et énunciation, narrateur et narration, le point narratif, l'espace et le personnage, nous centrons la discussion sur le concept du temps.

Nous distingons trois notions de temps: le temps physique, le temps interieur et le temps linguistique. Nous mettrons en évidence les deux derniéres notions. Nous les utiliserons comme axe pour l'étude des oeuvres, dans l'intention de vérifier comment les narrateurs-personnages voient leur passé et vivent leur présent.

Par rapport au temps linguistique, nous favoriserons l'étude de l'usage des verbes, entre outres mots temporels, pour que nous puissons vérifies les éffes de sens dans le choix des deus auteurs. Quand au temps intérieur, qui n'est pas mésuré par une montre, mas par l'intensité avec lequelle les personnages vivent diffeérents moments, nous mettons en évidence la relations des personnages avec le passé.

Egalement, en raison des différences marqueés entre les genres de romans, nous destinons une grande partie de ce travail à l'étude des genres narratifs.

\section{MOTS-CLEF}




\begin{abstract}
The aim of this paper is to weave a set of relations, at the light of the Comparative Literature, between the novels O Amanuense Belmiro (Cyro dos Anjos, 19XX) and Para Sempre (Vergílio Ferreira, 19XX), highlighting similarities and differences in a way such as to provide a deeper understanding of them.

To cope with this task, after briefly considering some concepts related to the novel composition, like the enunciation and the enunciated, the narrator and the narrated, the point of view, the setting, and the character, we centered the discussion over the concept of time - making a tripartite distinction among time notions: the physical, the internal, and the linguistic, with emphasis on the latter two - using it as an axis in the study of the novels, seeking to verify how the character-narrators see through their past and live their present.

With regard to the linguistic time, we gave particular attention to the study of verbs, detached from other temporal words, in order that we could note the meaning effects resulting from the authors' verb choices; as for the internal time, which is not measured by the clock, but by the intensity with which the characters go through different moments, we focused our study on the relation of the characters with the past.

Also, owing to the clear difference between the types of novel analyzed, we dedicated a considerable effort to the study of the narrative genre.
\end{abstract}

\title{
KEYWORDS
}

TIME, SETTING, CHARACTER-NARRATOR, JOURNAL-NOVEL, INTIMATE-NOVEL 